\title{
Equilibrium with Divergence of Opinion
}

\author{
by \\ Edward M. Miller \\ Professor of Economics and Finance \\ University of New Orleans \\ New Orleans, LA 70148 \\ 504-280-6913 (work) \\ 504-280-6958 (fax) \\ 504-283-3536 (home)
}

February 15, 2000

\begin{abstract}
Because the less informed incorrectly estimate asset returns, they anticipate higher returns from their risky investments. They thus over-invest in risky securities. They are rewarded by higher total portfolio returns. Too high a proportion of less informed investors lowers the return on risky assets. Equilibrium requires that the less informed's rate of return equal the informed's. The less informed control a stable equilibrium percentage of total wealth. Because an individual's recent investment experience correlates with his terminal wealth, learning need not reduce the less informed's risky asset exposure. Implications exist for the slope of the return versus systematic risk curve.
\end{abstract}


Should we expect security markets to be efficient? Academicians usually argue that information is readily available and investors are intelligent and motivated. Practitioners and students often respond by pointing to less informed, or even ignorant, investors who did well in the market (Uncle Joe perhaps). The academician then admits that some less informed individuals exist. (What academician who grades exams could doubt this?) It is then argued that the less informed would normally lose money to the informed. Thus, the informed would come to manage the vast bulk of the investment funds, (assuming no new less informed investors enter the market). The less informed should end up managing such small sums that they have little effect on prices. Thus, the price setting process should be dominated by the well informed, wealthy investors.

Milton Friedman's statement of this position is widely quoted (1953, p. 175), "People who argue that speculation is generally destabilizing seldom realize that this is largely equivalent to saying that speculators lose money, since speculation can be destabilizing in general only if speculators on the average sell when the currency is low in price and buy when it is high."

However, recently a problem with this argument has been pointed out. In an efficient, or a mildly inefficient market, the informed may make money at the expense of the less informed. The reason for this is that financial theory predicts that risk taking is rewarded (see Reilly 1989, Bodie, Kane, \& Marcus 1993, Elton \& Gruber, 1995, or any other text). Those taking greater risks can earn a higher rate of return. Poor information and inadequate security analysis often lead to taking greater risks. If the return gained from the extra risk taken by the less informed exceeds the losses due to poor security selection, the less informed will experience a higher rate of return on their total portfolios than the better informed. The wealth of the less informed will grow more rapidly than the wealth of the informed. Of course, this argument assumes that all things other than information are being held 
constant. In particular, the less informed and the uninformed are presumed to have the same risk preferences.

As a simple example of this argument, consider the numbers reported in the widely used Reilly text (1989, p. 46), where stocks have expected earnings of roughly 10\% (the reported $9.9 \%$ rounded) and a large standard deviation of $21.1 \%$, and risk-free securities and bank accounts earn $4 \%$ (the reported 3.5\% rounded). As any finance text explains, investors choose the asset mix that maximizes their utility. Those that choose to buy more stock (because they are more tolerant of risk) earn more on average than those who are averse to risk and stay primarily, or even entirely, in bank accounts, bonds, and other low risk assets.

What determines the actual return earned by classes of investors, such as the less informed? I would suggest that it is their asset mix, the fraction of their assets put in stocks and other risky assets relative to that put in low risk assets, including bank accounts and bonds. Brinson, Hood, and Beebower (1986) found that for large pension plans, asset mix explained $93.6 \%$ of the variation in total portfolio return. Asset mix is likely to be just as important for classes of individual investors. To determine whether the less informed earn more than the informed, we must ask whether the less informed are more likely to invest in risky asset classes, such as stocks. It will be argued that they are.

How should we model the behavior of the less informed? I would suggest that ignorance leads to mistakes. These mistakes could arise from the widely discussed overreaction (De Bondt \& Thaler 1985, 1987, Jegadeesh \& Titman 1993) or from a tendency to hold losers too long (Shefrin \& Statman 1985). It could be from the errors that lie behind any of the numerous biases (Shefrin, 2000) and anomalies that have been discovered (see Jacobs and Levy 1988, or Haugen, 1999a, b, for a list and for references). However, the argument here doesn't really depend on the nature of the mistakes, merely that they occur. The simplest model is that their mistakes are random, equally likely to raise or lower 
the returns from the stock or bond being considered. Such errors might be thought of as being distributed approximately normally). The investors, while not all-knowing, and not perfectly informed, will be presumed to be rational, and to act rationally, given their knowledge. In particular, the reader can think of them as using Markowitz optimization, either formally or informally (i.e., making judgements that approximate optimization without formally going through an optimization process).

With random errors, a few securities will appear to provide extremely profitable opportunities. Suppose the less informed investors believe they have identified stocks that will yield 50\% per year. These investors believe the potential return for taking the risk of investing in such a stock to be an extra $46 \%$, rather than the true $6 \%$. Naturally, the less informed will invest more of their wealth in such high return opportunities than will the better informed investors.

Investors concentrate on the securities they believe will have the highest returns, and reduce their holdings of the others to zero. If the returns from a stock are underestimated, the holdings are typically reduced to zero. The asymmetry arises in some countries because short selling is prohibited. In the countries where short selling is allowed (such as the US) few investors are willing to make short sales. Among individuals, the less informed are unlikely to even understand the mechanics of short selling. Most American institutional investors are forbidden to make short sales.

Not surprisingly, the risky part of the less informed investors' portfolio is less diversified than that of the better informed investors. This need not imply that they are undiversified. Given the textbook assumptions (efficient market that is pricing consistent with the capital asset pricing model, lending rates equal to borrowing rates, no transactions costs or indivisibilities), each investor holds some of every stock. If less informed investors make errors, they will believe some stocks are over priced, and others under-priced, causing them to purchase more of the latter, and probably none of the 
former. However, if they are rational (as is here assumed) portfolios will still be designed to provide adequate diversification (see discussion below).

In at least one simple utility function, the fraction of the investor's wealth put into risky assets is proportional to the risk premium he anticipates earning on these risky assets. Other plausible utility functions would yield similar results. Admittedly, arguing that the less informed and less sophisticated investors go through a formal optimization process is unrealistic, but the resulting conclusion appears well founded.

The above argument does not depend on less informed investors' underestimating risk (although they probably do). ${ }^{1}$ All that is required is that they overestimate the returns from some stocks, which will normally be the ones they include in their stock portfolios. They may underestimate the returns from other stocks, but these are not included in the portfolio. Such overestimation is quite consistent with unbiased estimates of the returns from each individual stock, since the estimated returns conditional on selection for inclusion in the portfolio can be expected to be biased upwards.

Random overestimation implies that the less informed will invest a substantially greater proportion of their wealth in risky assets than the better informed. This outcome is especially likely if the investor believes he has identified several unusually good current opportunities (chances of a lifetime), but does not expect similar future opportunities.

One implication of the above is that (given the same wealth and risk preference) the less informed will play a greater role in the market for risky assets, such as stocks, than would otherwise be expected given their share of the population and wealth.

Given the traditional efficient market assumption, in which prices fully reflect available information, the expected rates of return on assets reflect only their systematic risk, as any standard textbook explains. It also follows that the expected return on any portfolio will depend only on its 
systematic risk. It then follows that the portfolios of the less informed, reflecting a higher level of systematic risk because of a higher proportion of stocks and other risky assets, should earn higher rates of return. Thus, the surprising conclusion is that the less informed investors should do relatively better than the informed investors, contrary to the speculations of Friedman and others.

Some readers may be bothered by the idea of markets being efficient in spite of the presence of less informed investors. The difficulty probably arises because the usual textbook treatment of efficient markets assumes everyone has perfect information. However, a belief in an efficient market does not require such an unrealistic assumption. Many uninformed trades cancel out other uninformed trades. More importantly, with many well informed investors, as well as many poorly informed investors, minor divergences from theoretically correct prices can persuade the better informed investors to hold the stocks that the less informed neglect. The result is close to an efficient market, even if not a perfectly efficient one. ${ }^{2}$

Black (1986) has pointed to the importance of noise in understanding financial markets. The above argument not only incorporates noise traders, but more importantly provides an explanation for why they may persist over time. De Long, Shleifer, Summers, and Waldman ${ }^{3}$ in a series of papers made the very important point (on which this paper builds), that less informed investors may earn a higher rate of return on their total portfolios (stocks plus risk free assets) because they believe they have a more favorable risk-return opportunity and hence invest in securities with a higher return. Thus, the wealth of the less informed may grow more rapidly than the wealth of the informed.

The above demonstration that the less informed investors should earn higher rates of return than better informed investors creates problems for efficient market theory. If they consistently earn more than the informed investors, their wealth should come to be a steadily greater percentage of the funds invested in the market, and the informed investor's percentage of the market should steadily shrink, 
approaching zero if given enough time. After a long enough period of time, the informed investors must control such a small share of total wealth that their trades (offsetting those of the less informed investors) can no longer insure efficient markets.

Notice this implies a logical inconsistency in mainstream theory. Markets are argued to be efficient because informed investors' trading keeps them efficient. This requires that informed investors control some appreciable fraction of the wealth. However, it was just shown that, in the long run, the share of the wealth of informed investors in equilibrium tends towards zero. Such near zero shares of the wealth held by informed investors implies that markets will not be efficient.

Actually, the situation is worse than that discussed above. Becoming well informed costs money (information and security analysis are not free). This should reduce the rate of return earned by those investors who become informed. This effect serves to pull the rate of return earned by informed investors even further below that earned by the less informed, making the textbook theory even less defensible.

Admittedly, a belief in the survival of the less informed or less rational traders does not require the absence of short selling. If random errors are made in the rates of return on securities, the return from taking on additional risk will be overstated, leading investors to take on riskier positions, producing the scenario described above.

There is a more theoretical point; in the long run those that maximize the geometric mean of their returns over time obtain the highest growth rates for a portfolio. This is achieved by investors with a logarithmic utility function. However, Samuelson (1971) has pointed out that rational investors need not have the logarithmic utility function that maximizes long run wealth growth. There may be individuals operating with less than perfect information whose strategies produce portfolios with a long run geometric average rate of return that exceeds those of more rational or better informed investors. 
The ratio of the wealth of one of these investors to a completely rational, well-informed individual increases the further one looks into the future. Given the wide variety of poorly informed strategies or irrational ones, it is highly likely that at least one of these has a higher expected long run geometric average rate of return than any of the strategies that rational individuals might adopt. In the long run (leaving aside saving and dissaving issues) if new investors do not enter or leave the market, these less informed investors will come to dominate the market, as has been pointed out by Shefrin \& Statman (1994) and Blume \& Easley (1992).

Usually, when a logical application of a theory leads to ridiculous conclusions (or ones demonstrably false), one looks to find an assumption behind the theory that is either incorrect, or a poor approximation of reality. One then replaces this assumption with a better one.

\section{WHY LESS INFORMED INVESTORS EVENTUALLY COME TO AFFECT PRICES}

As the percentage of wealth controlled by the informed investors decreases, eventually a point is reached where the buying of the less informed bids up some stock's price. Normally, this will occur after the informed have reduced their holdings to zero (i.e. are constrained by the relevant short selling restriction), and the few willing to go short have the largest positions they are comfortable with, or are legally allowed to hold.

Once this position is reached, further buying by the less informed must raise the price. This increased price draws forth additional selling, either from less informed investors, or from informed investors who are willing to take a larger short position if offered a higher price. At this point, the assumption of a flat market demand curve becomes untenable.

At what point this state is reached depends on several factors. One is the extent to which different, less informed investors are purchasing the same stock. If all less informed investors are making the same mistake, they will all be putting the same stocks into their portfolio in more than the market 
proportion, and the stocks will more quickly reach the level of holdings at which most informed investors have sold out.

If the less informed investors differ among themselves, some of the buying will be matched by the selling of other less informed investors. The net impact on the market will be reduced, and the wealth of the informed investors can shrink to a lower level before the buying by the less informed investors impacts appreciably on any stock prices. However, given the assumptions stated above, sooner or later the relative wealth of the informed investors will decline to such a low level that the assumption of efficient markets no longer holds.

The only exception to the above argument is if, through incredible luck, the less informed investors are buying stocks in exact proportion to the market portfolio. In this case, the share of the wealth held by the uninformed can keep growing faster than that of the informed. Thus, the share of the total wealth held by the informed investors will decline steadily towards zero. Only then can prices stay at the level predicted by efficient market theory even as the informed's share of the wealth approaches zero. This outcome is sufficiently unlikely that it need not be taken seriously.

Thus, let us drop the unrealistic assumption made earlier that informed investors can keep prices at the level predicted by efficient market theory. ${ }^{4}$ Instead, the less informed investors will be presumed to be able to bid prices up. Such bidding up of prices lowers the rate of return earned on these securities. For instance, one might imagine that the less informed could bid up by $25 \%$ the prices of the stocks found most attractive, before the lowered return discouraged any further purchasing. If this happens, the set of stocks that the less informed think promise high returns might actually yield only $8 \%$ (this is the $10 \%$ a typical stock would have earned, divided by 1.25$)$. Such lower returns on their stocks obviously reduce the returns on their total portfolios, but still leave it possible for the aggregated portfolios of the less informed to outperform the aggregated portfolios of the better informed. Fortunately, it is easy to 
calculate whether with this lower return the total (risk free assets included) portfolios of the less informed would still outperform the total portfolios of the informed. ${ }^{5}$ If the less informed's aggregate portfolios would still outperform that of the better informed, their share of wealth would keep growing.

\section{AN EQUILIBRIUM WEALTH DISTRIBUTION?}

The above suggests an equilibrium distribution of wealth between the less informed and the informed (or across different ability levels). The reason is that unless the wealth distribution is such that the wealth of the informed and the less informed grow at an equal rate, the fraction of total wealth controlled by one group will be changing. As explained below, increasing the share of wealth controlled by either group lowers that group's rate of return, thus slowing the growth of that group's wealth. Conversely, a decrease in the share of wealth of either group increases that group's rate of return, thus increasing that group's rate of wealth growth. Thus, there are equilibrating forces that tend to return the shares of wealth to the level where the wealth of both groups grow at the same rate.

If the relative rates of return on total portfolios are the same for two groups (and if both groups' net consumption are equal percentages of their total wealth), the two portfolios will grow at equal rates, leaving the equilibrium wealth distribution unchanged. The logic is trivial. Let $\mathrm{W}_{\mathrm{i}}$ be the informed initial wealth, $\mathrm{W}_{\mathrm{u}}$ be the less informed initial wealth, $\mathrm{r}_{\mathrm{i}}$ be the rate of return over one year earned by the informed on their total portfolio, and $r_{u}$ be the rate earned by the less informed. After one year informed wealth is $\left(1+r_{i}\right) W_{i}$, and less informed wealth is $\left(1+r_{u}\right) W_{u}$. The wealth ratio after one year $\mathrm{R}$ is given by

$$
\mathrm{R}=\left(1+\mathrm{r}_{\mathrm{i}}\right) \mathrm{W}_{\mathrm{i}} /\left(1+\mathrm{r}_{\mathrm{u}}\right) \mathrm{W}_{\mathrm{u}}
$$

If $r_{i}=r_{u}$, it follows that the new wealth ratio is $\mathrm{W}_{\mathrm{i}} / \mathrm{W}_{\mathrm{u}}$ which was the original ratio. Thus, if the equilibrium distribution of wealth between the informed and less informed investors is somehow achieved, it will persist. 
To refer to this distribution of wealth as an equilibrium one it is necessary to show that if the distribution of wealth is other than this, there are mechanisms that return the distribution to this "equilibrium state."

Insert Figure 1 here

The basic argument can be seen on Figure 1, which plots the difference in total portfolio returns versus the wealth ratios for the informed and the less informed investors. Remember the total portfolio is defined to include both the risk-free and the risky assets. Line ABC shows how the differential return declines as the wealth ratio increases. A horizontal line is drawn through the value of 0 for the difference in the total portfolio rates of return. Only when there is no difference (i.e. the difference is 0 ) does the wealth ratio remain stable. The equilibrium value for the wealth ratio occurs where this horizontal line is cut by the line $\mathrm{ABC}$. Of course, an equilibrium value for this ratio implies an equilibrium share of total wealth for the less informed.

If the income distribution differs from that required for equal total portfolios, rates of return will change so as to move the wealth distribution towards this equilibrium. If the informed have less than their equilibrium share of wealth, the difference of the total return ratio will exceed 0 . This situation is shown by a position on the line AB. Their wealth will increase relative to that of the less informed. This is shown by the direction of the arrow. This movement will continue until the equilibrium at B is reached.

If the ratio of the informed wealth to the less informed wealth exceeds the equilibrium ratio, the differences in their total rates of return will be below 0 . This situation corresponds to a position on line BC. The ratio of the informed's wealth to the less informed's wealth will decline, causing a movement along line BC towards B. This is shown by the arrows. Again, the movement will continue until the equilibrium at $\mathrm{B}$ is reached. 
Thus, if the ratio of the informed's wealth to the less informed's wealth is other than $\mathrm{D}$, forces arise in the form of different rates of return on the respective total portfolios, which tend to return the ratio to its equilibrium value. Thus, the equilibrium situation requires that the total wealth of the two classes grow at the same rate.

The argument can be put in symbols. Let the subscript i refers to the informed, and the subscript $\mathrm{u}$ to the less informed, $\mathrm{w}$ to the fraction of wealth in risky assets, and $\mathrm{R}_{\mathrm{f}}$ to the risk free rate of return, $R_{i}$ is the return to risky investment for the informed, and $R_{u}$ the return for the less informed. If $w_{i} R_{i}+\left(1-w_{i}\right) R_{f}>w_{u} R_{u}+\left(1-w_{u}\right) R_{f}$, then the fraction of total wealth in the informed's portfolios will increase. This will cause $R_{i}$ to decrease until $w_{i} R_{i}+\left(1-w_{i}\right) R_{f}=w_{u} R_{u}+\left(1-w_{u}\right) R f$. If $w_{i} R_{i}+\left(1-w_{i}\right) R_{f}<$ $\mathrm{w}_{\mathrm{u}} \mathrm{R}_{\mathrm{u}}+\left(1-\mathrm{w}_{\mathrm{u}}\right) \mathrm{R}_{\mathrm{f}}$, then the fraction of wealth controlled by the less informed will increase, causing $\mathrm{R}_{\mathrm{u}}$ to decrease until again $\mathrm{w}_{\mathrm{i}} \mathrm{R}_{\mathrm{i}}+\left(1-\mathrm{w}_{\mathrm{i}}\right) \mathrm{R}_{\mathrm{f}}=\mathrm{w}_{\mathrm{u}} \mathrm{R}_{\mathrm{u}}+\left(1-\mathrm{w}_{\mathrm{u}}\right) \mathrm{R}_{\mathrm{f}}$.

Thus, the distribution of wealth between the less informed and the informed will be such that $\mathrm{w}_{\mathrm{i}} \mathrm{R}_{\mathrm{i}}+\left(1-\mathrm{w}_{\mathrm{i}}\right) \mathrm{R}_{\mathrm{f}}=\mathrm{w}_{\mathrm{u}} \mathrm{R}_{\mathrm{u}}+\left(1-\mathrm{w}_{\mathrm{u}}\right) \mathrm{R}_{\mathrm{f}}$, regardless of the initial wealth distribution.

\section{SOME SIMPLE NUMBERS}

To see if such an equilibrium is consistent with plausible numbers, let us look at some simple numbers. If the informed invest half their wealth in stocks earning $10 \%$, and invest half in risk-free assets earning $4 \%$, their average return would be $7 \%$. If the less informed have bid certain stocks up so that they earn only $8 \%$, this could be offset by their having three quarters of their wealth in stocks, and only a quarter in risk-free assets. They would also earn 7\%. The wealth of both groups would then be growing at $7 \%$ per year, and there would be an equilibrium.

What would be required to induce the less informed investors to put three quarters instead of half of their assets in stocks? Suppose both groups of investors have a simple quadratic utility function that causes one believing the risk premium to be $6 \%$ to invest half of their assets in stocks. All that would be 
necessary for the less informed to invest three quarters of their assets in stocks, would be for them to be convinced that the set of stocks they intended to invest in would earn $13 \%{ }^{6}$ Such an outcome seems possible.

Imagine the less informed have a portfolio building rule of investing in the 25 best stocks (a number believed adequate for diversification). Suppose the universe of stocks contains a thousand stocks, whose average return is expected to be $10 \%$. However, the less informed make small errors in estimating the returns from these thousand stocks, and conclude they have identified 500 they think will outperform the market (i.e. have positive alpha). Since they desire a portfolio with 25 stocks, they choose the top $5 \%$ of these for inclusion in their portfolio. It seems very plausible that their errors could be large enough to convince themselves that this 25 stock portfolio will outperform the market by $3 \%$. (Unbiased estimates of expected returns whose standard error is $1.5 \%$ would be more than adequate to produce the hypothesized overestimation, since a $3 \%$ excess return is approximately 2 standard deviations away from the mean). They would anticipate an expected return of $13 \%$ from their chosen portfolio. This would be adequate to induce them to keep three quarters of their wealth in stocks.

Indeed, it seems implausible for a market to be so perfect that the informed never err about the expected returns from stocks, and the less informed have a standard error of only 1.5 percentage points. Yet, such a minor imperfection in forecasting of means by some investors can sustain a market in which some stocks are priced to yield $8 \%$ and others $10 \%$. Larger errors could yield markets with greater imperfections.

The author does not find it implausible that it would take many years (even using sophisticated statistical methods) for the investors who thought they were good enough to pick a 25 stock portfolio (out of an universe of a thousand stocks) that would have an expected return of $13 \%$ to discover that 
their stock portfolios only earned $8 \%$, and that a shift to a new forecasting technique (or a new advisor) would not solve the problem.

Boldt and Arbit (1984, p. 30) have pointed out that it would take 30 years of data to confirm at the $95 \%$ probability level that a manager able to earn an excess return of $7.1 \%$ was not merely benefitting from measurement error. This point, which has been made repeatedly in different forms, is usually used to argue against selecting managers on the basis of historical success. However, the same problem affects individuals trying to evaluate their own relative skill. Even if they keep accurate records of their investment performance, it will take many years of experience for them to have statistically significant evidence that they have, or do not have, skill.

It is easy to imagine death eliminating investors before they learn that they, or their advisors, lack expertise. Their place in the less informed group would be taken by new investors who thought they could beat the market by $3 \%$.

For simplicity, the analysis has been done with only a single group of less informed investors. There could be several groups of less informed investors. For instance, some may trade excessively and experience much reduced returns. Another group may be very gullible and fall regularly for frauds. Such investors have low, or even negative returns. Over time such investors' share of the total wealth declines. Thus, the less informed investors that drive this model are not grossly uninformed (although such may exist), but those whose errors have the primary effect of causing them to purchase more of the risky assets than they otherwise would. It is these investors who are most likely to affect prices.

\section{IMPLICATIONS FOR INVESTORS}

Notice the equilibrium described here differs from the standard efficient markets equilibrium. In an efficient market there is no opportunity to identify securities that offer higher than normal risk adjusted returns using publicly available information. Thus the best that can be done is to diversify widely, 
minimize the resources devoted to researching securities, and minimize turnover by a buy and hold strategy.

In contrast, in the model outlined here, there could be some overvalued and undervalued securities that can be identified with publicly available information. Securities that are popular with the less informed investors are bid up, causing them to have lower rates of return. Other securities, whose merits the less informed don't recognize, have higher returns. In the example discussed initially, the less informed had bid certain securities up by $25 \%$, causing the expected return (as estimated by the informed investors that made the effort to estimate it) to fall to $8 \%$, when other investments were earning $10 \%$. If analysis could separate the $8 \%$ stocks from the $10 \%$ ones, the increase in returns could justify the increased expense of an active investment policy, especially for investors that have substantial sums to invest (such as institutional investors).

Such a market has been called a bounded efficient one (Miller 1987). Investment analysis covers its cost not by finding winners, but by avoiding losers (Miller 1978). The optimal strategy becomes to study a small portion of the universe of stocks intensely, hoping to identify overpriced ones that the less informed have bid up. Once these have been identified, and enough stocks have been purchased to provide the desired diversification, additional search brings few gains (and has costs). When the stocks the informed buy are earning 10\% (if of average risk), identifying more $10 \%$ stocks does not raise the average return earned by the portfolio. Thus, informed investors do not take a position in all available stocks, but only in those correctly priced for the risk.

Finally, notice that the above model provides a clear rationale for security analysis. In the academic efficient market model, there is no reason to do security analysis, and hence no reason to hire security analysts. In the above model, with a large number of less informed investors bidding certain 
stocks up, it is possible for the better informed investors to earn more than the less informed through security analysis. This provides a rationale for the existence of security analysts.

\section{THE EFFECT OF LEARNING}

Many believers in textbook efficient market models will argue that investors could not consistently deceive themselves, convincing themselves that they can pick stocks well, while experiencing normal or even subnormal returns. Admittedly, a long series of disappointments may cause investors to shift towards a more conservative strategy. However, security returns are highly variable, and it is easy to rationalize away failures and attribute success to genius. A failure can be attributed to a mistake that has now been learned from, and hence will not be repeated.

Unfortunately, many individuals do not realize the power of compound interest. A stock investor who earns the average $10 \%$ per year will double his money in a little more than 7 years. Doubling your money is impressive, and it is easy for such an investor to convince himself that he has unusual skill which will prevent the losses others experience.

It is important to remember that high risk portfolios have highly variable outcomes. Many holders of such portfolios do very well. And many do very poorly. Let us look at the plausible reactions of each of these groups of individuals to their experiences. Those who have done very well attribute their success to skill rather than luck. They are likely to conclude that they (or their advisors) indeed have the ability to select high return stocks. As a minimum they will continue with their high risk, ignorance-based strategy. If anything, they are likely to increase the fraction of their wealth invested in risky assets. Possibly, they will borrow to increase the amount invested.

Admittedly, there will be many investors who are unlucky as well as less informed, or imprudent. Some of these may learn from their experience. Many of them will merely decide what their mistake was, and resolve to avoid it in the future. Unfortunately, there are many possible mistakes to be made, and 
they are free to make another. Again, if their errors are random, these errors will lead them to believe they have some very high return opportunities available, if they will only accept the risk. Again, they may be lucky or unlucky. If lucky, they act as described in the previous paragraph, and continue investing heavily in risky assets. If unlucky, they again identify their mistakes, decide to avoid making them a second time, and proceed to make new ones.

Admittedly, this sequence may continue long enough so that the investors eventually learn. What they have to learn is the psychologically difficult fact that they are not as smart, or not as informed, as they would like to think. Many people will not admit this to themselves. This tendency to believe good things about ourselves actually serves useful psychological purposes. For one thing, it is generally in our interest to have others believe good things about ourselves. In turn, it is hard to persuade them to hold these opinions if we do not hold them about ourselves. Evolutionary psychologists believe that such abilities to deceive ourselves were probably selected for during evolution (Lockard \& Paulhus, 1988; Trivers, 1990).

The alternative is to master the extremely sophisticated idea that when there are random errors in estimation, one is likely to systematically overestimate the returns from a project if one acts as if one's best estimates were truly the expected returns from the project. This is true even if one's estimates are, on average, unbiased estimates of the expected returns. This is a very difficult concept to master (judging from the author's difficulty in communicating it to $\mathrm{PhD}$ and MBA students) which was introduced to the professional finance literature only in the late seventies. ${ }^{7}$ Since the idea is still not in the MBA textbooks, few of the less informed investors will discover it on their own.

In considering whether investors will continue with less than optimal strategies (such as investing on their own estimates of the potential returns), it is important to remember what psychologists have discovered in animal conditioning experiments. Rats have been found to continue longer in a particular 
behavior pattern if they are rewarded on a random schedule (a variable ratio schedule) than if they are rewarded every time the desired action is performed. Gambling is argued to be reinforced on such a variable ratio schedule (Kalat 1990, p. 264).

The theory applied to gambling probably also extends to investing in risky assets. If less informed investors are occasionally rewarded for investing in risky assets by large winnings, they are likely to persist in their investment behavior for a long time, probably longer than if they were consistently rewarded with small winnings. Indeed, being consistently rewarded with small winnings is more likely to be the experience of the well informed investor. After making accurate estimates of the returns from different assets, the well-informed investor diversifies widely and then puts much of his wealth into a riskfree asset.

However, it is plausible that investors learn, and eventually those who have a long run of moneylosing stocks will reduce the percentage of their wealth invested in stocks. However, the important thing to notice is that bad luck and ignorance may have already reduced their wealth to the level where altering their asset allocation will have little market impact.

Consider two less informed investors who each invests $\$ 20,000$ in stocks, convinced they each have exceptional skill. After several years, the unlucky one has reduced his money to a fifth of what he had, or $\$ 4,000$. He finally concludes he lacks skill, and decides to take a fifth of his wealth out of the market. There is now $\$ 800$ less invested in stocks.

What of the other investor, the lucky one? To be symmetrical with the one who has lost all but a fifth of his money, imagine his stocks have risen fivefold. His $\$ 20,000$ in stocks is now $\$ 100,000$. He also is capable of learning from experience. Seeing his stunning investment success, he decides he is a good stock picker. He decides to put an amount equal to $20 \%$ of his wealth more into the market (This requires opening a margin account). This decision raises his commitment to risky assets by $\$ 20,000$. 
Notice what learning has done. The net effect of investor learning is that the lucky one increases the amount committed to risky assets by $\$ 20,000$, and the unlucky one decreases it by $\$ 800$. The net effect is an $\$ 19,200$ increase in the money in the market.

Yes, investors do learn from their experience. However, the interaction of luck and learning from experience implies that, all other things being equal, those who have earned high rates of return have more money than those who have earned low rates of return. If learning leads to equal percentage shifts in wealth committed to risky assets (or similar effects through adjusting estimated future returns), those with favorable experience will have more wealth, and will shift more money into risky assets than the unlucky investors with poor recent experience will shift away from risky assets. Thus, allowing for learning can increase the tendency for the less informed class of investors to invest a higher fraction of their wealth in risky assets, and to earn a higher return on their total portfolios, increasing the fraction of the market's wealth they control.

Because of the correlation of wealth with historical experience, reevaluations of skills based on investment experience may easily increase the stock commitment of the less informed investors, taken as a group. These are the ones who are most likely to evaluate their expertise by their recent experience, rather than doing a correct Bayesian assessment that includes correct prior probabilities (based on the expertise and motivation of competitors) for them actually having unusual expertise.

\section{CONCLUSIONS}

Because the less informed tend to make more errors in evaluating returns on risky assets, they anticipate higher returns from the risky assets they choose. This causes them to invest more of their total wealth in risky securities. In a perfectly efficient market, where all securities have the same risk adjusted returns, this will cause the less informed investors to earn higher total returns. 
However, a higher return (not offset by differences in saving rates) on one group's portfolio implies that this group's share of total wealth will increase. A perpetually increasing share of wealth for the less informed group is inconsistent with the continuance of efficient markets.

For equilibrium with multiple groups, the rate of growth of the wealth of each group must be the same. In the absence of saving differences, this implies that differences in the fraction of wealth invested in risky assets must be offset by differences in the average risk premiums earned on risky assets. This equilibrium, and the forces maintaining it, can be shown with a simple graph.

Differences in saving behavior between groups can be easily incorporated into the model.

Because errors in return estimation likely correlate with systematic risk, the slope of the security market line is reduced because less informed investors bid up the prices of securities whose systematic risk is high.

It is unlikely that learning will eliminate this effect for several reasons. Some are psychological. However, because an individual's investment experience is correlated with his end of period wealth, equal percentage shifts in the allocation to risky assets (or equivalent changes in beliefs) increase total funds allocated to risky assets.

\section{Footnotes}

${ }^{1}$ There are several reasons for suspecting that estimation errors may both overestimate returns and underestimate risks. One is that people in general tend to be overconfident (Shefrin, 2000, pp. 48-51) and this leads to underestimating risks.

One reason is that there is a large number of things that can go wrong (lawsuits, entry of competitors, new government regulations, product recalls, etc.) which are individually of low probability, but collectively important. To simplify the analysis investors often place the probability of 
these events at zero, rather than at the correct low number. Failure to consider the possibility of such adverse events both raises returns and lowers risks.

Also, both firms and brokers have incentives to promulgate good news and information about the possibility of favorable events. Thus, most less informed investors are likely to have heard about possible good news (say a new product in development, or the potential cost saving from a new management). However, there is less incentive to publicize bad news, and the less informed investors may not have discovered some adverse facts.

${ }^{2}$ Certainly there is considerable evidence that markets are close to efficient (for a recent review, see Fama 1991). The consistent failure of institutional investors to outperform the averages shows that markets are close to efficient, even if not perfectly efficient (Dunn and Theisen 1983, Brinson, Hood, and Beebower 1986, Bogle 1991, Figures 4 and 5, Lakonishok, Shleifer, and Vishny 1992). As long as mistakes do not appreciably change the rates of return on the securities bought because of these mistakes (which requires merely that mistake-inspired trades be offset by better informed investors' trades), the portfolios of the mistake prone, being riskier, should earn higher rates of return than the portfolios of the informed. Of course, this assumes that the uninformed do not trade so often as to lose most of their income through spreads and commissions.

Admittedly, Ippolito (1989) reported that mutual funds slightly outperformed the indices, a fact which he interpreted as showing some stock picking ability. However, most of this advantage was consumed by management fees and other expenses, as theory would predict. Thus, even conceding this degree of skill, the wealth in these mutual funds would not be growing faster than that of less expert individual investors who did not have the mutual funds' management expenses. 
${ }^{3}$ De Long, Shleifer, Summers, and Waldman, (1991) have argued that some investors frequently make errors in estimating variability of security returns, normally being overconfident about their predictions, and have shown that such investors can survive and possibly come to dominate in markets. They give very little consideration to incorrect estimates of rates of return, saying (p. 5), "Moreover we assume the misperceptions of different noise traders about a particular asset are correlated, for if all traders confused about the returns on a stock have different misperceptions, their trades will cancel out." I explicitly do not make this assumption here.

While De Long et al. (1990b, p. 731) assert that equity underpricing "is a necessary condition for noise traders to earn higher expected returns," this argument shows they can earn higher returns simply because they put more of their total portfolio into risky assets, and more into risky assets with higher systematic risks, regardless of whether equities as a whole are underpriced. An earlier statement by the same authors (De Long et al. 1990a, p. 731) states, "Finally, as we showed in earlier work, if trader's mistakes cause them to take positions that carry more market risk than rational investor's positions, they can earn higher return in the market even if they make judgement errors." However, in their 1991 paper these authors clearly recognize and show that investors who err about individual securities can earn higher returns. The earlier work referred to, while not explicitly referenced, is apparently an earlier draft of the noise paper (here referenced as De Long et al. 1990b). Finally, in a summary paper, Shleifer and Summers recognize that noise traders can earn higher expected returns in the market through undertaking higher risks, but they make the puzzling comment that "Almost for sure, they fail to affect demand in the long run" (1990, p. 25). 
${ }^{4}$ Readers may ask why the case of uninformed investors forcing prices down is not discussed. There are several reasons. One is that the arguments are symmetric, and if the case of prices being forced up is understood, the case of prices being forced down is the reverse.

However, there are several reasons for concentrating on the case where the uninformed bid prices up. One is that most uninformed investors are probably unwilling or unable to sell short. Many individual investors do not understand short selling, and hence will not engage in it. The uninformed investors are likely to be disproportionately represented in this group. Thus, if they underestimate returns from a stock, they are likely to reduce their holdings to zero, and then stop selling. This limits the amount of downward pressure on prices their mistakes cause.

Consider, a case where investors make errors of plus or minus $20 \%$ in the expected returns from stocks in a market where the average stock is believed to yield 10\%. Most investors making downwards errors will reduce their holdings to zero. Few will sell short. Hence those who do not hold the stock (typically a majority) will not be willing to go short, and will do no selling. The effective impact on the market will be limited, and most likely offset by buying from the informed investors, leaving the price unchanged.

However, every investor who overestimates the return by $20 \%$ is likely to be a buyer (even if holdings had previously been zero). This makes it much more likely that the error-induced buying will be large enough to change the price. Thus, the concentration in the body of the text on error-induced buying rather than error-induced selling.

${ }^{5}$ The total earnings of the informed investors $\mathrm{R}_{\mathrm{ti}}$ is given by

$$
\mathrm{R}_{\mathrm{ti}}=\mathrm{R}_{\mathrm{f}}+\mathrm{w}_{\mathrm{i}}\left(\mathrm{R}_{\mathrm{i}}-\mathrm{R}_{\mathrm{f}}\right)
$$

and for the uninformed investors by 


$$
\mathrm{R}_{\mathrm{tu}}=\mathrm{R}_{\mathrm{f}}+\mathrm{w}_{\mathrm{u}}\left(\mathrm{R}_{\mathrm{u}}-\mathrm{R}_{\mathrm{f}}\right)
$$

where $\mathrm{w}$ is the fraction of wealth in risky assets, $\mathrm{R}_{\mathrm{f}}$ to the risk free rate of return, $\mathrm{R}_{\mathrm{i}}$ is the return to risky investment for the informed, and $\mathrm{R}_{\mathrm{u}}$ the return for the uninformed. The subscript $\mathrm{i}$ refers to the informed investors, and the subscript $\mathrm{u}$ to the uninformed ones. The total rate of return on the portfolios of the uninformed will exceed that of the informed if

$$
w_{u} / w_{i}>\left(R_{i}-R_{f}\right) /\left(R_{u}-R_{f}\right)
$$

In words, the necessary condition for the uninformed investors to earn more on their total portfolio is for the fraction of their portfolio invested in risky assets to rise by a higher percentage than the reciprocal of the fraction by which the risk premium they earn on risky assets is reduced. For this to happen seems quite plausible.

${ }^{6}$ See footnote 1 for the demonstration that the percentage of assets in the risky assets is proportional to the anticipated risk premium for such a utility function. If the less informed investors believe the risk premium on the set of stocks they will purchase is $9 \%(13 \%-4 \%)$, rather than $6 \%(10 \%-4 \%)$, they will invest 50\% more in stocks than the fully informed investors.

${ }^{7}$ See Miller 1978 for an exposition (the first to my knowledge), with a worked out example.the most recent exposition is Miller (forthcoming). 


\section{REFERENCES}

Black, Fischer, (1986), 'Noise,' Journal of Finance XLI, 529-543.

Black, Fischer, Michael C. Jensen, and Myron Scholes, (1972). 'The capital asset pricing model: some empirical tests', in Michael C. Jensen ed., Studies in the Theory of Capital Markets, New York, NY, Praeger.

Blume, Lawrence \& David Easley (1992). 'Evolution and market behavior,' Journal of Economic Theory $58,9-40$.

Blume, Marshall \& Irwin Friend, (1975). 'The asset structure of individual portfolios and some implications for utility functions' Journal of Finance_ XXX, 585-603.

Bodie, Zvi, Alex Kane, \& Alan J. Marcus, (1993). Investments, Homewood, IL, Richard D. Irwin.

Boldt, Bob L. \& Hal Arbit, (1984). 'Efficient markets and the professional investor' Financial Analysts Journal, 22-34.

Bogle, John C., (1991). 'Investing in the 1990s: Remembrance of things past and things yet to come' Journal of Portfolio Management, 5-14.

Brinson, Gary P., L. Randolph Hood, \& Gary L. Beebower, (1986). 'Determinants of portfolio performance,' Financial Analysts Journal 42, 39-44.

Copeland, Thomas E. \& J. Fred Weston, (1988). Financial Theory and Corporate Policy, Reading, Mass., Addison-Wesley.

De Bondt, Werner F. \& Richard Thaler, (1985). 'Does the stock market overreact?' Journal of Finance XL, 793-805.

De Bondt, Werner F. \& Richard Thaler,(1987). 'Further evidence on investor overreaction and stock market seasonality,' Journal of Finance 42, 557-581. 
De Long, J. Bradford, Andrei Shleifer, Lawrence H. Summers, \& Robert J. Waldman, (1990a), 'Positive feedback investment strategies and destabilizing rational speculation,' Journal of Finance_45, 379395.

De Long, J. Bradford, Andrei Shleifer, Lawrence H. Summers, \& Robert J. Waldman, (1990b). 'Noise trader risk in financial markets,' Journal of Political Economy 98, 703-738.

De Long, J. Bradford, Andrei Shleifer, Lawrence H. Summers, \& Robert J. Waldman,(1991). 'The survival of noise traders in financial markets,' Journal of Business 64, 1-20.

Dunn, Patricia \& Rolf D. Theisen,(1983). 'How consistently do active managers win?' Journal of Portfolio Management 9, 47-50.

Elton, E. J. \& Gruber, M. J., (1995). Modern Portfolio Theory and Investment Analysis, Nw York: John Wiley \& Sons.

Fama, Eugene F., (1991). 'Efficient Capital Markets: II,' Journal of Finance XLVI, 1575-1617.

Friedman, Milton, (1953). 'The case for flexible exchange rates,' in Essays in Positive Economics, Chicago, IL, University of Chicago Press.

Grossman, Sanford J. \& Joseph E. Stiglitz, (1980), 'On the impossibility of informationally efficient markets,' American Economic Review 70, 393-408.

Haugen, R. A., 1999a. The New Finance: A Case against Efficient Markets, Upper Saddle River, New Jersey: Prentice Hall

Haugen, R. A., 1999b. The Inefficient Stock Market, Upper Saddle River, New Jersey: Prentice Hall. Ippolito, Richard A., (1989) 'Efficiency with costly information: A study of mutual fund performance, (1965-(1984,' The Quarterly Journal of Economics CIV, 3-23.

Jacobs, Bruce J. \& Kenneth N. Levy, (1988) 'Disentangling equity return regularities: New insights and investment opportunities,' Financial Analysts Journal 44, 18-44. 
Jegadeesh, Narasimhan \& Sheridan Titman, (1993). 'Returns to Buying Winners and Selling Losers: Implications for Stock Market Efficiency,' Journal of Finance XLVIII, 65-91.

Kalat, James W., (1990). Introduction to Psychology, Belmont, Mass., Wadsworth.

Lakonishok, Josef, Andrei Shleifer, \& Robert W. Vishny, (1992). 'The structure and performance of the money management industry,' Brookings Papers on Economic Activity, Microeconomics, 339-379.

Lockard, J.S. \& D.L. Paulhus. (1988). Self-deception: An Adaptive Mechanism? Englewood Cliffs, NJ: Prentice Hall.

Miller, Edward M., (1977). 'Risk, uncertainty, and divergence of opinion,' Journal of Finance 32, 11511168.

Miller, Edward M., (1978). 'Uncertainty induced bias in capital budgeting,' Financial Management 7, 1218.

Miller, Edward M., (1978). 'How to win at the loser's game,' Journal of Portfolio Management 5, 17 24.

Miller, Edward M., (1987). 'Bounded efficient markets: A new wrinkle to the EMH,' Journal of Portfolio Management 13, 4-13.

Miller, Edward M, (forthcoming). "Capital Budgeting Errors Seldom Cancel," Financial Practice and Education.

Reilly, Frank K., (1989). Investment Analysis and Portfolio Management, Chicago, IL, The Dryden Press.

Samuelson, Paul, (1971). 'The 'fallacy' of maximizing the geometric mean in long sequences of investing or gambling,' Proceedings of the National Academy of Science of the United States 68:10, 24932496. 
Shefrin, Hersh \& Meir Statman, (1985). 'The disposition to sell winners too early and ride losers too long: theory and evidence,' Journal of Finance XL, 777-790.

Shefrin, Hersh (2000). Beyond Greed and Fear. Boston: Harvard Business School Press.

Shefrin, Hersh \& Meir Statman, (1994), 'Behavioral capital asset pricing theory,' Journal of Financial and Quantitative Analysis 29:3, 323-349.

Shleifer, Andrei \& Lawrence H. Summers, (1990). 'The Noise Trader Approach to Finance,' Journal of Economic Perspectives 4:2 Spring 19-33.

Shukla, Ravi, \& Charles Trzcinka, (1991)'Research on risk and return: Can measures of risk explain anything?' Journal of Portfolio Management 17, 15-21.

Statman, Meir, (1987). 'How many stocks make a diversified portfolio?' Journal of Financial and Quantitative Analysis 22, 353-364.

Trivers, R. (1990. Deceit and self-deception: The relationship between communication and consciousness. In: Man and Beast Revisited. M.H. Robinson and L. Tiger, Eds, Washington: Smithsonian, pp. 175-(191. 


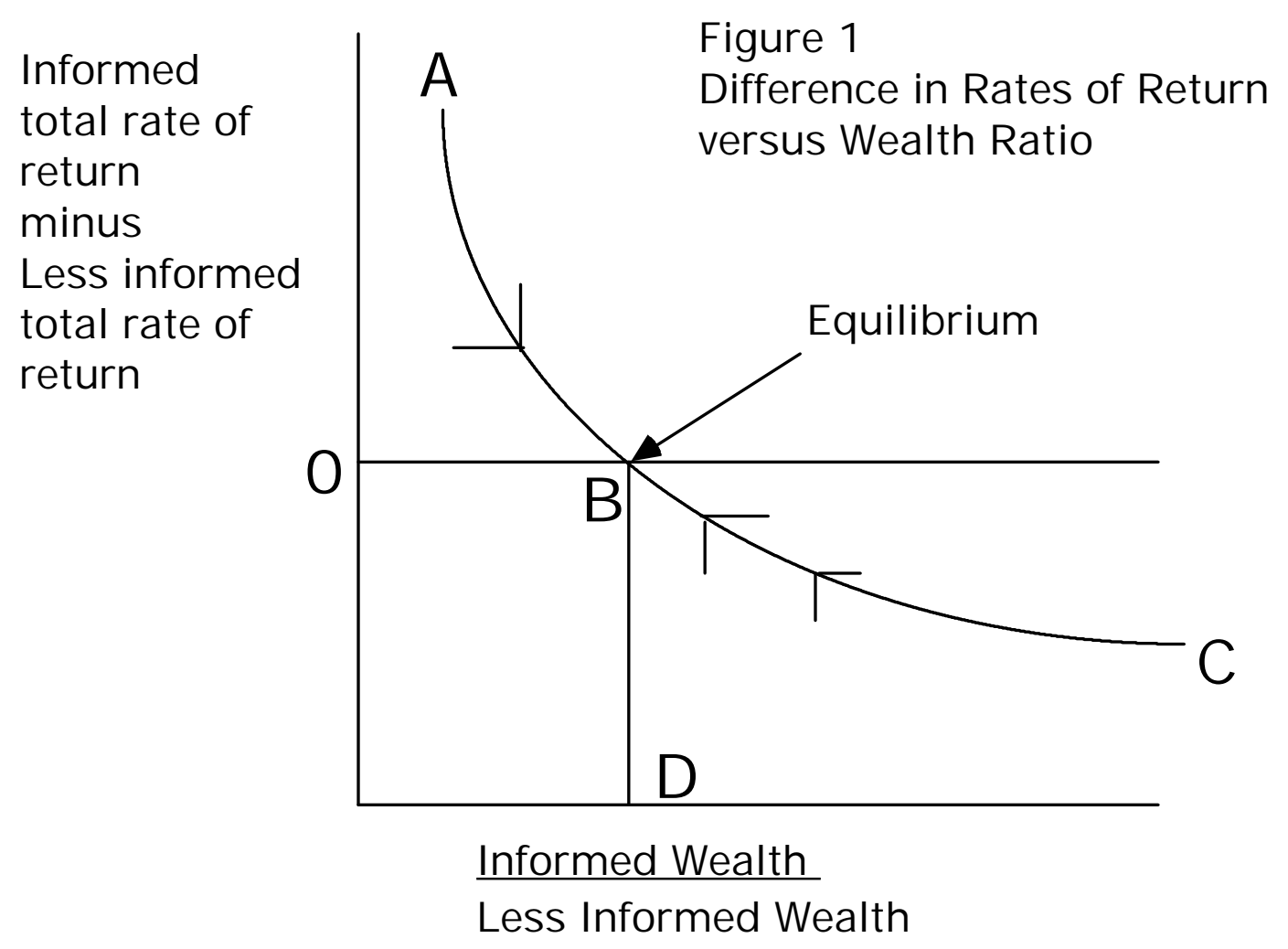

